\title{
MORPHOLOGICAL VARIATION IN THE WILD-WEEDY COMPLEX OF SORGHUM BICOLOR IN SITU IN WESTERN KENYA: PRELIMINARY EVIDENCE OF CROP-TO-WILD GENE FLOW?
}

\author{
James A. Okeno, ${ }^{1,2, *}$ Evans Mutegi, ${ }^{1,3}{ }^{3} \dagger$ Santie de Villiers, $\neq$ Jeffrey D. Wolt, ${ }^{*}$ and Manjit K. Misra* \\ *Seed Science Center/Biosafety Institute for Genetically Modified Agricultural Products, lowa State University, Ames, lowa 50011, U.S.A.; \\ tKenya Agricultural Research Institute, National Gene Bank of Kenya, P.O. Box 30148, Nairobi, Kenya; and ‡International \\ Crops Research Institute for the Semi-Arid Tropics, P.O. Box 39063-00623, Nairobi, Kenya
}

\begin{abstract}
Crop wild relatives are important components of agroecosystems and have over the years been exploited in breeding programs as sources of genes for novel traits. Information on the extent and patterns of variability is important in formulating effective conservation and utilization strategies for existing crop wild relative populations. We conducted surveys and collections of wild and weedy accessions of Sorghum bicolor (L.) Moench in Lambwe Valley in western Kenya in order to investigate occurrence, distribution, and morphological variability in the wild-weedy complex of S. bicolor under local agroecological conditions. We also attempted to understand the role, if any, of crop-to-wild gene flow in structuring variability within and among populations. The morphological data presented here showed wide variability within wild-weedy sorghum populations with respect to habitats and morphotypes. True wild sorghum populations in national parks and the sugarcane belt were clearly distinguishable from the putative hybrids or intermediate forms found in sorghum fields, in sorghum field margins, and, to some extent, by the roadside near sorghum fields. The existence of these intermediate forms is empirical evidence of introgression between cultivated sorghum and its wild-weedy relatives. Extensive introgression, especially within in situ conservation areas and/or in areas of high diversity, would lead to genetic erosion and possible depletion of these important wild sorghum genetic resources.
\end{abstract}

Keywords: morphological diversity, sorghum, farmer practices, introgression.

\section{Introduction}

Sorghum bicolor (L.) Moench is a highly diverse species that belongs to the genus Sorghum of the tribe Andropogoneae. It has been divided into three subspecies, namely, bicolor, verticilliflorum, and drummondii (Doggett 1988). Subspecies bicolor is recognized as consisting of five basic races-bicolor, kafir, caudatum, durra, and guinea-and an additional 10 intermediate races (Harlan and de Wet 1972). The four wild races or congeners verticilliflorum, arundinaceum, virgatum, and aethiopicum are recognized in the subspecies verticilliflorum (Doggett 1988). Subspecies drummondii is a heterogeneous group composed of all the intermediate forms between wild and cultivated sorghums across the African continent. Sorghum is believed to have originated in northeast Africa, where it was domesticated $\sim 3000-5000 \mathrm{yr}$ ago (Mann et al. 1983; Ejeta and Grenier 2005). It has been proposed that modern sorghums have diverse origins, with

${ }^{1} \mathrm{~J}$. A. Okeno and E. Mutegi contributed equally to the work described in this article.

2 Author for correspondence; e-mail: jaketch@iastate.edu.

${ }^{3}$ Current address: Department of Evolution, Ecology, and Organismal Biology, Ohio State University, 318 West 12th Avenue, Columbus, Ohio 43210, U.S.A.

Manuscript received October 2011; revised manuscript received February 2012. the cultivated subspecies bicolor arising from the wild subspecies verticilliflorum. It is thought that the wild race aethiopicum gave rise to durra and bicolor cultivated races, while wild races arundinaceum and verticilliflorum gave rise to guinea and kafir types of sorghum, respectively (Mann et al. 1983). De Wet and Huckabay (1967) and de Wet et al. (1970), however, were of the opinion that durra sorghum arose from kafir.

When cultivated crops and their wild/weedy relatives occupy the same or overlapping locations, are sexually compatible, have overlapping flowering times, and share a common pollination mechanism, there is a high likelihood for gene flow to occur between them. For sorghum, several studies have shown that interspecific and intraspecific hybridization between cultivated sorghum and its wild/weedy relatives takes place (Doggett 1988; Doggett and Prasada Rao 1995; Paterson et al. 1995; Arriola and Ellstrand 1997; Ellstrand et al. 1999; Morrell et al. 2005). A survey of 283 loci by Morrell et al. (2005) found that the putative cultivar-specific alleles were in $>32 \%$ of Johnsongrass (Sorghum halepense [L.] Pers) interspecific populations that were growing near sorghum production fields for extended periods. Additional molecular and genetic analyses, obtained in Africa, established that crop-specific alleles can be found in intraspecific wild relatives of sorghum when they are grown in close proximity, further suggesting that intraspecific hybridization and introgression occur (Doggett and Majisu 1968; Aldrich and 
Doebley 1992; Aldrich et al. 1992; Mutegi et al. 2011). Regions in Africa and other parts of the world that hold high diversity of crop sorghum landraces and their wild/weedy relatives are of special interest for conservation policies. Tanksley and McCouch (1997) considered such regions as "genetic insurance," where lost alleles through domestication and modern breeding can be recovered by falling back to the crop wild relatives or ancestors. Mutegi et al. (2010) suggested that special efforts should be directed in recording and mapping wild sorghum populations in Kenyan national parks as possible further evidence to estimate the extent and direction of historical and recent gene flow between cultivated and wild sorghum for contribution to the national genetic resource conservation policy.

Sorghum is a vitally important crop in Africa and much of the developing world. It has a remarkable ability to endure both drought conditions and waterlogging, and it grows well on marginal lands. It is the dietary staple of more than 500 million people in more than 30 countries, with only rice, wheat, maize, and potatoes feeding more people than sorghum. Sorghum, together with pearl millet and finger millet, are listed as some of Africa's main contributions to its food supply (de Vries and Toenniessen 2001). Sorghum cultivation in Africa is predominantly found among peasant, subsistence, and smallholder-farming communities, where most production is consumed at home directly as food (porridge, ugali) and the stover is fed to livestock. Sorghum, therefore, is a good candidate in Africa for reducing rural poverty, combating hunger and malnutrition, and accelerating growth (Millennium Development Goal 1). Toward addressing the importance of sorghum in contributing to global food security, there has been a substantial interest in understanding the genetic diversity of both cultivated and wild/weedy sorghum by using morphological traits (Tesso et al. 2008; Barnaud et al. 2009; Mutegi et al. 2010), DNA markers (Djè et al. 2000; Casa et al. 2005; Mutegi et al. 2011), or both morphological and DNA markers (Barnaud et al. 2007; BarroKondombo et al. 2010). Such information is vital for making informed decisions as regards to policy development for preserving genetic resources, its management, and utilization in breeding programs. Most of these studies except one (Barnaud et al. 2007) involved materials collected on a national scale as opposed to a local or village scale. We therefore chose to conduct surveys and collections of wild and weedy sorghums within Ruma National Park and adjacent farms in Lambwe Valley and also in the sugarcane belt in Migori District of Suba District, both of greater South Nyanza, western Kenya. This area is known to host many wild-weedy sorghum taxa. In this region, farmers mainly carry out traditional farming methods and maintain their own sorghum landraces. Since it was important not only to study gene flow and genetic diversity based on biological traits but also to gather knowledge on farmer practices, we also collected samples of cultivated sorghum varieties and recorded farmer knowledge of these varieties, that is, landrace vernacular names, uses, seed origin, and so on. This information is important to allow for the investigation of the role, if any, of agroclimatic and farmer practices on gene flow and genetic diversity in the crop-wild-weedy complex of Sorghum bicolor in situ. Data on the movement of genes from cultivated sor- ghum to its co-occurring wild/weedy relatives in cultivated and natural habitats is important for conservation of genetic resources near or around the Ruma National Park. Currently, there is no information available on where such studies have been conducted. The objectives of this study were to (1) carry out local-scale surveys and collections of wild and cultivated sorghum samples from Ruma National Park and adjacent farms in Suba District and in sugarcane belt in Migori District of greater South Nyanza, western Kenya, that host crop-wild-weedy sorghum complexes; and (2) analyze morphological diversity within the wild-weedy S. bicolor complex at the agroecosystem and/ or local scale and document any morphological evidence of crop-to-wild gene flow in these in situ populations. The ability to discriminate gene flow within the crop-wild-weedy complexes on the basis of morphology represents an important tool for the management of agricultural systems to conserve genetic resources.

\section{Material and Methods}

\section{Study/Sampling Area}

Field surveys were carried out in Lambwe Valley of Suba District, which houses Ruma National Park and its adjacent farms. Ruma National Park was gazetted in 1966 as Lambwe Valley Game reserve and acquired national park status in 1983. It lies on the flat floor of Lambwe Valley, surrounded by settled lands with a mix of small-scale cultivation of various crops, including sorghum, and grassy pastureland. The park is a valuable island of natural habitat in a sea of human settlement. Like other protected lands, it is an important reservoir for plant genetic resources, especially crop wild relatives. To provide a contrast with a sorghum farming system, the survey was extended into the Awendo sugarcane belt in the neighboring Migori District.

Our study aimed at acquiring samples of wild sorghum from the park as well as wild-weedy sorghum from different habitats within and around sorghum fields. An exploratory survey was first conducted in the target region during the last week of June 2009. The purpose of the survey was to (1) ascertain the presence of wild sorghum within Ruma National Park; (2) identify the optimum time for simultaneously collecting samples of cultivated and wild sorghum, since the latter tends to mature earlier; and (3) identify and map potential sites for collecting populations of cultivated sorghum and its wild-weedy relatives. Subsequently, a sample collection trip was conducted in the first 2 wk of July 2009.

Various habitats were selected for crop-wild gene flow analysis and comparison among populations of cultivated and wild sorghum with different levels of spatial overlap (table 1). The habitats were classified and abbreviated as (1) sorghum fields (sf), where wild types were co-occurring with the cultivated counterparts; (2) sorghum field margins (fm), in close proximity (less than $5 \mathrm{~m}$ ) to cultivated sorghum; (3) disturbed ground by the roadside ( $\mathrm{rd}$ ) but close to cultivated sorghum (5-10 m); (4) sugarcane fallow (sc) in a zone where sorghum is not grown; and (5) protected land in a national park/wildlife sanctuary (pk). The sf represented habitats of complete crop-wild intermix, whereas fm and rd represented intermediate habitats close to farmlands. The pk represented 
Table 1

Geographical Coordinates of Wild Sorghum Populations and Sampling Sites

\begin{tabular}{lccc}
\hline Sampling site & Population code & Latitude $\left({ }^{\circ} \mathrm{S}\right)$ & Longitude $\left({ }^{\circ} \mathrm{W}\right)$ \\
\hline S1 & sf1 & -.55642 & 34.29691 \\
S2 & sf2 & -.55796 & 34.28625 \\
S2 & rd & -.55796 & 34.28625 \\
S3 & fm & -.66900 & 34.05918 \\
S4 & pk1 & -.62407 & 34.26198 \\
S5 & pk2 & -.58695 & 34.26075 \\
S7 & sf3 & -.72887 & 34.07066 \\
S8 & sc & -.93209 & 34.55222 \\
\hline
\end{tabular}

Note. sf1, wild/weedy sorghum population from sorghum field 1 ; sf2, wild/weedy sorghum population from sorghum field 2; sf3, wild/ weedy sorghum population from sorghum field 3 ; rd, wild/weedy sorghum population from roadside; fm, wild/weedy sorghum population from sorghum field margin; $\mathrm{pk} 1$, wild/weedy sorghum population from national park sampling area $1 ; \mathrm{pk} 2$, wild/weedy sorghum population from national park sampling area 2; sc, wild/weedy sorghum population from sugarcane fallow; $\mathrm{S} 1-\mathrm{S} 8$, sampling sites 1-8.

a natural habitat isolated from cultivation, while sc represented farmland habitat away from sorghum cultivation. In total, eight distinct populations of wild-weed sorghum were sampled in the above-mentioned five contrasting habitats from collection sites S1, S2, S3, S4, S5, S7, and S8 (see table 1). The number of wild/weedy sorghum individuals in each of these populations was greater than 100 , with the exception of rd, which had approximately between 50 and 100 individuals. All collection sites within each habitat were georeferenced using a hand-held GPS and location coordinates used to generate a collection map using DIVA GIS (fig. 1).

To investigate morphological variability within and between the wild-weedy sorghum populations, five random plants were chosen from each sampled population of 25 plants and data recorded on five quantitative (plant height, number of internodes, number of basal tillers, panicle length, panicle width) and four qualitative (panicle shape, presence/absence of awn, glume color, glume cover) traits. In each case, data were recorded from the main flowering tiller and for the first growth. Each of the five individuals in each population was categorized as either true wild (w) or putative hybrid (h), using morphological observation as described previously by Doggett (1988). Examples of the two types of wild-weedy sorghum based on panicle characteristics are shown in figure 2. Putative hybrids were characterized by compact to semicompact panicles (fig. $2 \mathrm{~A}$, $2 B$ ), while true wilds had open and loose panicle types (fig. $2 C, 2 D)$.

\section{Statistical Analysis}

All data were analyzed using R.2.11.1 software ( $\mathrm{R}$ Development Core Team 2008). Basic descriptive statistics (mean, range, and standard deviation) were calculated for the five quantitative traits based on the entire data set. Univariate ANOVA was performed on the five quantitative traits to explore the level of variation among the eight populations.
Principal component analysis (PCA) was performed on a data matrix of the five quantitative traits and 40 representative individuals in order to explore patterns of association and major traits contributing to the delineation. Input data were standardized to minimize the effect of scale on variability weighting. Patterns of grouping among individuals were visualized by plotting the first two principal components (PCs) of the PCA. A hierarchical cluster analysis was further performed based on Gower's dissimilarity coefficient (Gower 1971), as implemented in the algorithm DAISY (Kaufman and Rousseeuw 1990) of the package CLUSTER in R. This procedure enabled generation of a pairwise dissimilarity matrix for cluster analysis using both qualitative and quantitative data. The dissimilarity matrix was further subjected to analysis of similarity (ANOSIM), implemented in the package VEGAN of R, to compare patterns of variation within and among populations, within and among habitats, and within and between wild-weedy types (h, putative hybrid; w, true wild) for multiple morphological characters. ANOSIM tests for differences between groups in a manner analogous to ANOVA by comparing withingroup (population or habitat) similarity to between-group similarity, with $P$ values determined randomly (Legendre and Legendre 1998). The distances in the dissimilarity matrix are converted to ranks, so that the smallest distance ranks $(r)$ as 1 . The ANOSIM statistic $R$ is thus based on differences of mean ranks between groups $\left(r_{\mathrm{B}}\right)$ and within groups $\left(r_{\mathrm{W}}\right)$ :

$$
R=\frac{r_{\mathrm{B}}-r_{\mathrm{W}}}{[N(N-1)] / 4}
$$

where $N$ is the total number of individuals. Values of $R$ range from 0 (no difference between groups, i.e., null hypothesis) to 1 (complete divergence between samples). Significance testing was obtained using 10,000 permutations.

\section{Results}

Wild sorghum populations were abundant and widely distributed in the national park (pk). Most of them occupied disturbed grounds by the pathways or roadsides and below the trees in pasture grassland, although a few individuals were scattered among shrub or tree thickets. A few wild or weedy sorghums were found intermixed with cultivated landraces in sorghum fields (sf). However, large wild sorghum populations were seen growing in close proximity to sorghum crop, particularly in sorghum field margins ( $\mathrm{fm}$ ) and by the roadsides (rd). In the sugarcane farming system (sc), there were only few wild sorghum plants, found mainly along sugarcane fallows. Wide variability is found within the studied wild-weedy sorghum populations for all quantitative traits measured (table 2). Variation was also highly significant $(P \leq 0.001)$ among populations for these traits. Patterns of morphological variability are further summarized and compared among the eight wild-weedy populations using box plots (fig. 3). Generally, populations of wild-weedy sorghum found in cultivated sorghum fields (sf) were characterized by panicles that are shorter (fig. $3 A$ ) and more compact (fig. $3 B$ ) than their counterparts in the park or sugarcane 


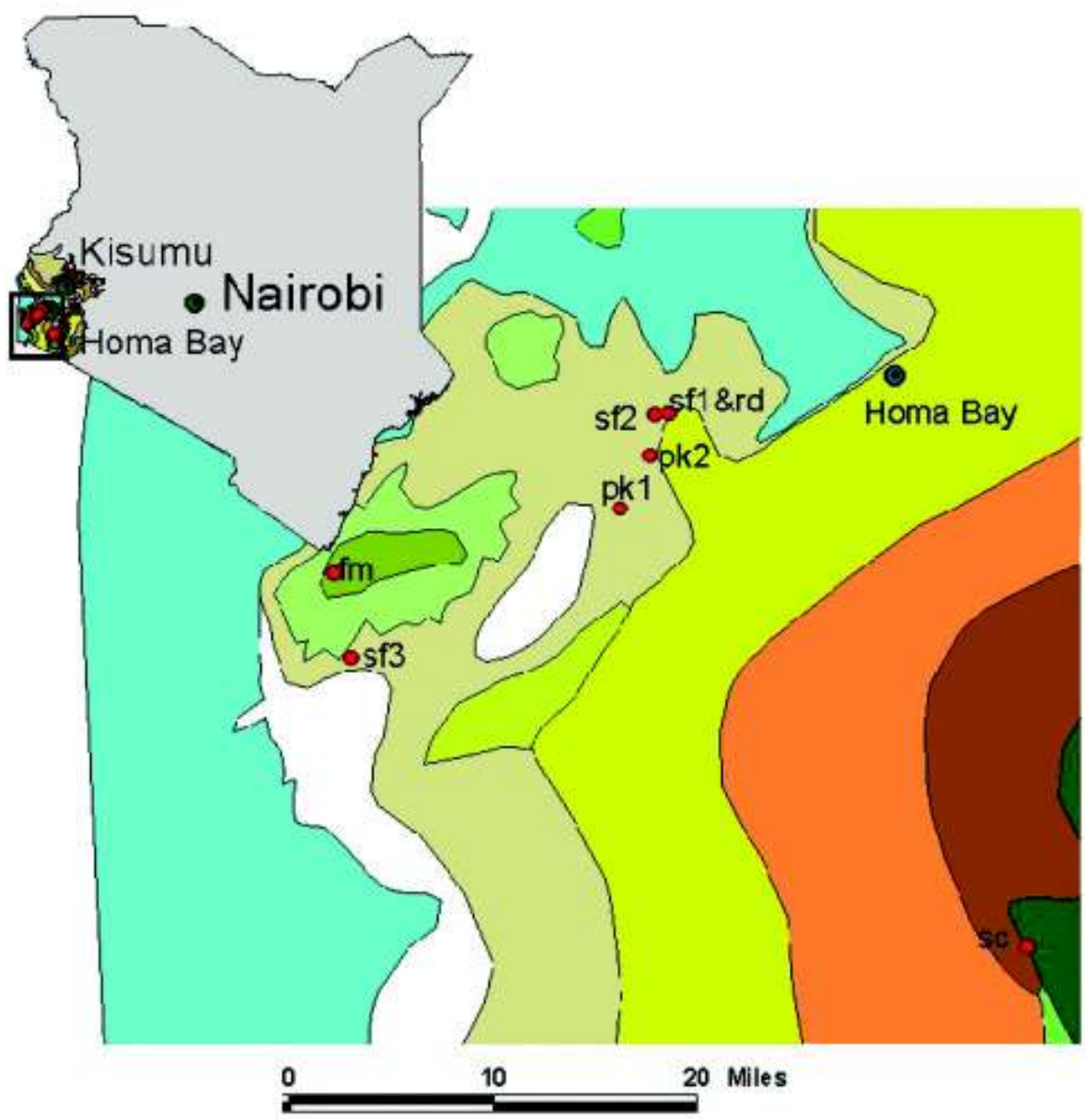

- Collection sites
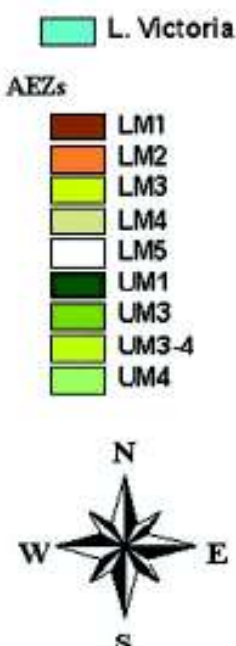

Fig. 1 Map of the study area (location in Kenya is shown by a smaller inset map at the top left) with sampled populations and agroecological zones (AEZs) shown. LM, lower midland; UM, upper midland.

field. Furthermore, populations of wild-weedy sorghum cooccurring with cultivated sorghum were taller in height than their counterparts in the nonsorghum growing habitats (fig. 3C). A similar trend was observed for number of internodes (fig. $3 D$ ). The images presented in figure 2 support the box plot results for panicle characteristics. These morphological appearances of wild/weedy individuals were used to categorize the populations as either putative crop-wild hybrid or true wild. Populations of wild/weedy sorghum occurring in field margins (fm) and roadside (rd) habitats appeared to be morphologically intermediate between those in sorghum fields (sf) and those in noncultivated sorghum habitats (pk, sc). We therefore classified wild sorghum plants from the $\mathrm{pk}$ and sc habitats as true wilds and those from sf and $\mathrm{fm}$ as putative crop-wild hybrids. No consistent patterns were observed among the populations for the number of basal tillers (fig. 3E).

Specific patterns that defined the way the five quantitative traits were associated to influence the components of the PCA are presented in table 3. The first three PCs explained more than $90 \%$ of the variation among individuals. The first component, PC1, explained more than half $(56 \%)$ of the var- iability, with high negative loadings from plant height and number of internodes and high positive loadings from panicle length and panicle width. The second PC explained 19.1\% of the total variability and was mainly described by the number of basal tillers with high negative loadings. The third PC accounted for $15.8 \%$ of the total variability and was most heavily weighted by plant height, panicle length, and panicle width. A biplot of PC1 and PC2 further revealed two major morphotypes. Individuals identified in the field as putative hybrids were clearly separated from those classified as true wilds by PC1 with negative and positive scores, respectively (fig. 4). The putative hybrids were characterized by tall plants with a high number of internodes and with panicles that were largely short and compact. Contrastingly, plants categorized as true wilds were generally shorter with a low number of internodes and with panicles that were generally long and broad. Furthermore, putative hybrids appeared to separate into two groups, one made up exclusively of individuals from two (sf1 and sf2) of the three sorghum field populations (group A) and another (group B) made up largely of individuals from field margins alongside those from the third sorghum field (sf3) population (fig. 4). Notably, members of 
A

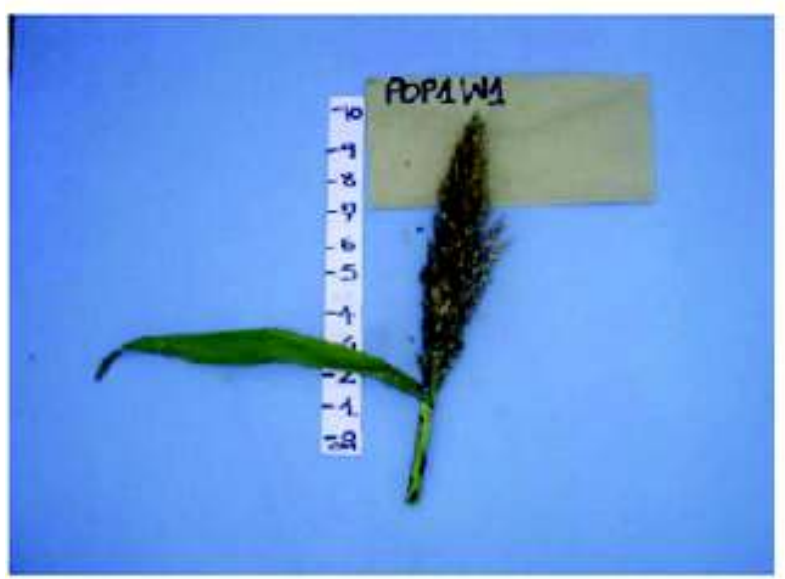

C

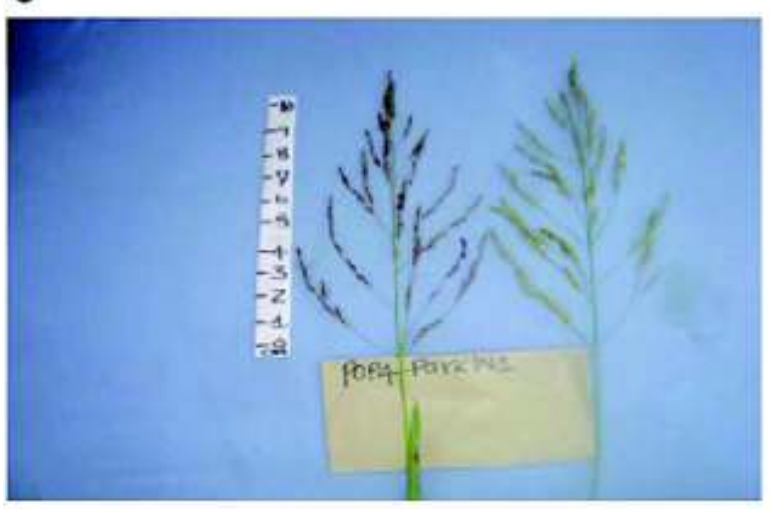

B

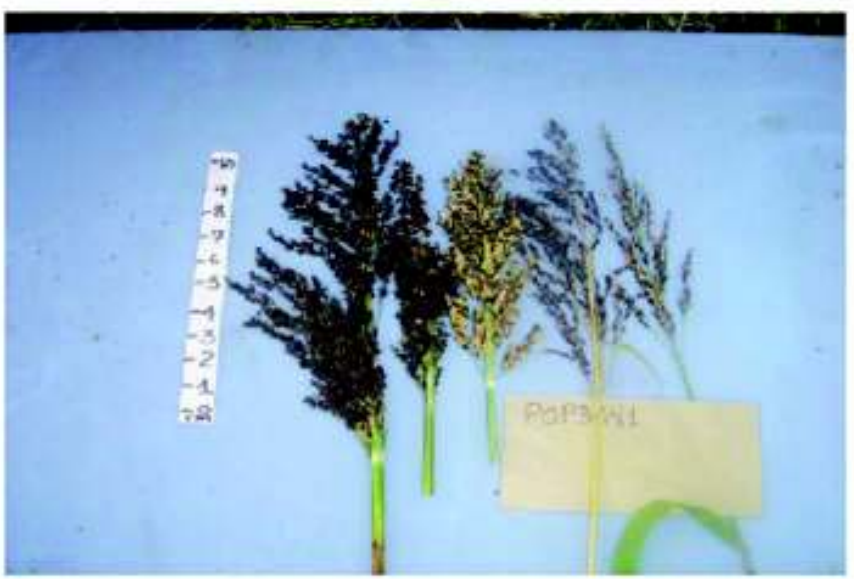

D

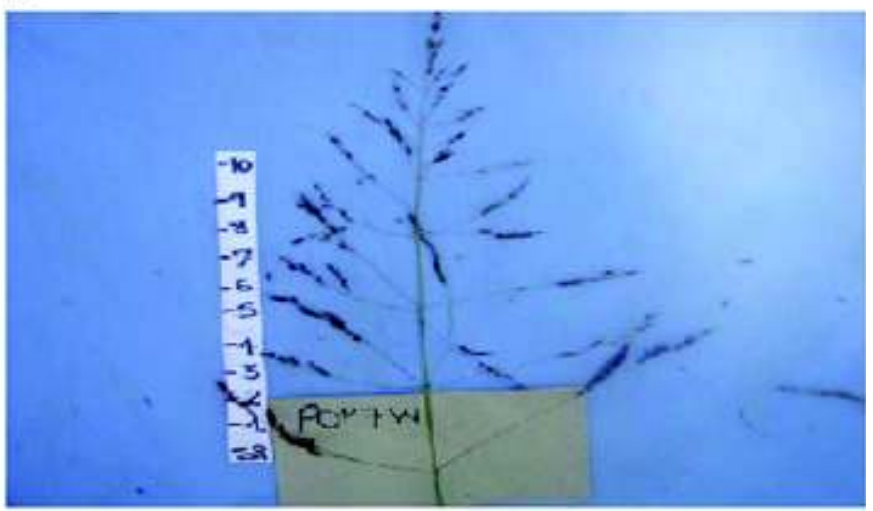

Fig. 2 Images showing different types of wild-weedy sorghum panicles. $A$ and $B$ are typical of putative hybrids and were mostly found in sorghum fields, while $C$ and $D$ are typical of true wild, with the former being found in the park and the latter in a sugarcane field.

group A were characterized by shorter and more compact panicle types relative to their counterparts in group B, confirming the observation in the box plot.

\section{Cluster Analysis}

Hierarchical cluster analysis revealed a high level of variability among the wild-weedy sorghum individuals, with an overall dissimilarity level slightly below $80 \%$ (fig. 5). Three major clusters were evident at an $\sim 56 \%$ level of dissimilarity, with a clear delineation between putative hybrids and true wilds. Cluster A was exclusive to putative hybrid individuals from sorghum fields, whereas cluster B contained mostly putative hybrids from intermediate habitats ( $\mathrm{fm}$ and rd). All except two members of cluster $\mathrm{C}$ were of the true wild category and were drawn largely from habitats well isolated from sorghum fields (pk and sc), even though $\sim 20 \%$ proportion of individuals in this group were from intermediate habitats ( $\mathrm{fm}$ and $\mathrm{rd}$ ). Overall, there was close congruence between PCA and cluster analysis results. ANOSIM revealed highly significant morphological variability among popula- tions $(R=0.76, P<0.001)$, habitats $(R=0.48, P<0.001)$, and wild-weedy sorghum type $(R=0.57, P<0.001)$.

\section{Discussion}

\section{Morphological Diversity and Distribution of Wild/Weedy Sorghum}

Our study found high morphological variability in the wild/weedy sorghum, with significant differentiation indicated among populations, habitats, and morphotypes. This result is consistent with the diverse and highly heterogeneous nature of the species Sorghum bicolor (Doggett 1988). Our finding is compatible with previous findings on a national scale in Kenya (Mutegi et al. 2010) and on a local scale in northern Cameroon (Barnaud et al. 2009). Furthermore, our analysis underscores the potential that exists for utilizing these diverse wild/weedy relatives in broadening the genetic base of sorghum breeding germplasm and, particularly, as sources of genes for novel traits such as resistance to pests and diseases (Duncan et al. 1991; Sharma and Franzmann 2001; Kamala et al. 2002, 2009; Reed et al. 
Table 2

Mean, Minimum, Maximum, SD, and $F$-Test Significance $(P)$ for Five Quantitative Traits from ANOVA

\begin{tabular}{lccrrc}
\hline Trait & Minimum & Maximum & Mean & \multicolumn{1}{c}{ SD } & $P$ \\
\hline Plant height $(\mathrm{cm})$ & 189.0 & 381.0 & 282.1 & 59.73 & $.001^{*}$ \\
No. internodes & 5.00 & 15 & 8.7 & 2.81 & $.001^{*}$ \\
Panicle length $(\mathrm{cm})$ & 8.00 & 49 & 31.1 & 9.59 & $.001^{*}$ \\
Panicle width $(\mathrm{cm})$ & 6 & 40 & 21.1 & 10.51 & $.001^{*}$ \\
No. tillers & 0 & 15 & 3.4 & 3.48 & $.001^{*}$ \\
\hline
\end{tabular}

Note. ANOVA performed on five traits recorded from 40 individuals among eight wild-weedy populations.

* Highly significant.

2002). There exists a need to systematically conserve these important plant genetic resources through scientifically informed in situ and ex situ approaches (Maxted et al. 2010). The observation of abundant and widespread distribution of wild sorghum in Ruma National Park highlights the conservation importance of in situ conservation sites. Ruma National Park has remained a government-protected animal sanctuary since 1966 . However, we observed that some sorghum fields were in close proximity (less than $10 \mathrm{~m}$ ) to the fence of the national park, a situation that clearly poses a risk of pollen-mediated crop-to-wild introgression and thus genetic contamination of in situ conserved wild sorghum populations.

Within farmlands, wild sorghums were more prevalent in intermediate habitats (i.e., field margins, roadsides, and fallows) than in crop fields. This result may be explained by negative selection pressure applied by farmers through weeding. On the basis of our questionnaire with farmers in this area, we learned that they consider wild sorghum as weeds and control them manually through rouging. Sometimes it is impossible for farmers to distinguish between weedy and cultivated forms of sorghums, especially before flowering. Some plants therefore persist to harvesting time, when they are easily distinguished by the farmers and left standing in the fields. Most of the wild populations we encountered in sorghum fields were of this type. After harvest, it is a common practice for farmers to graze their cattle on crop residues including weedy types. In the process, the weedy sorghums would be further dispersed to other crop fields, open fallows, field margins, and/or roadsides. Cattle in this area may thus play an important role in dissemination and survival of wild sorghum, including the putative hybrids. Overall, not only did our findings confirm that variation in distribution of wild sorghums in various habitats is attributable to agricultural practices (Ejeta and Grenier 2005), they also confirmed that wild populations
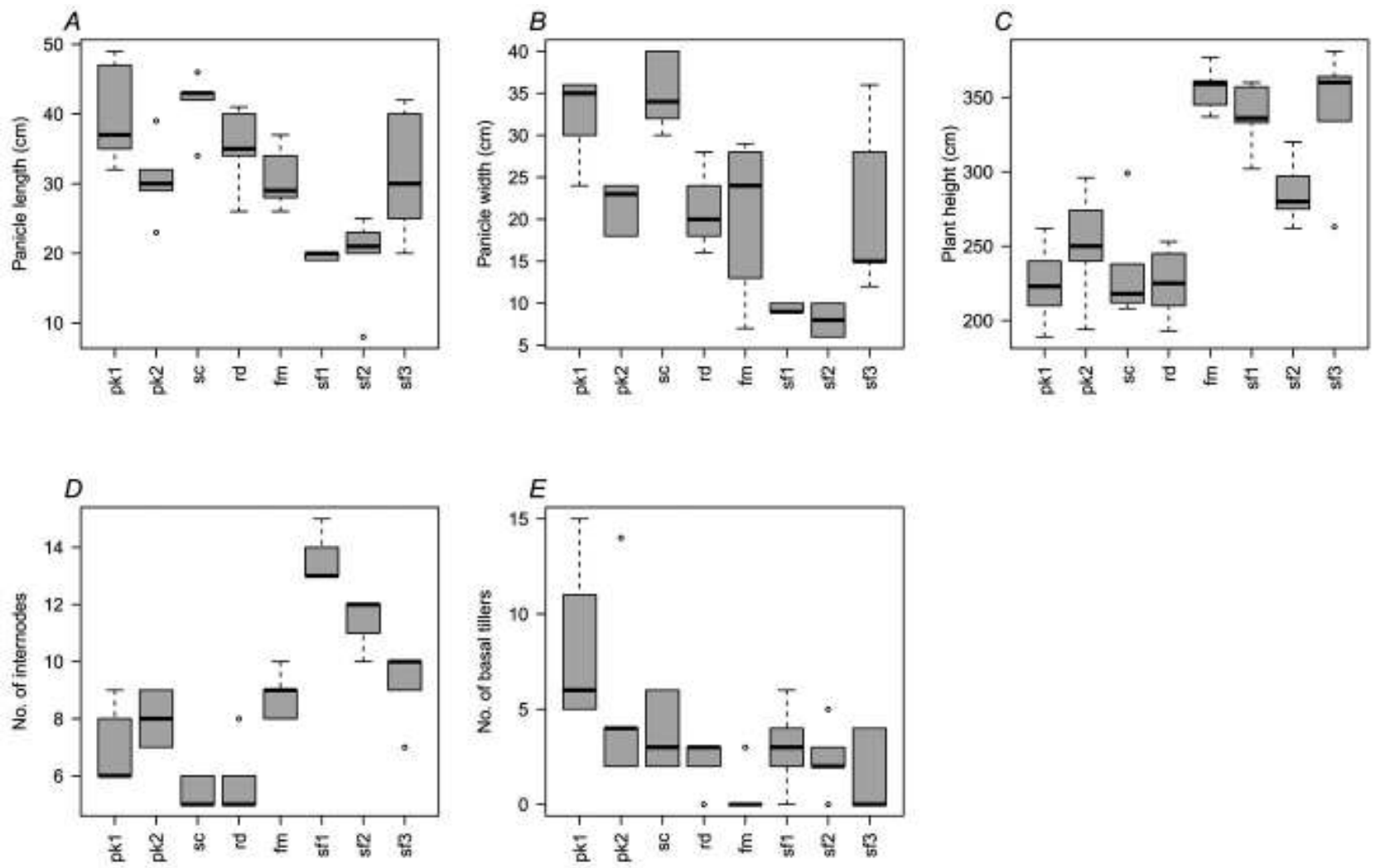

Fig. 3 Box plots showing variability in panicle length $(A)$, panicle width $(B)$, height $(C)$, number of internodes $(D)$, and number of basal tillers (E) for the eight populations of wild-weedy sorghum in this study. The box presents the interquartile range (50\% of values), while the line across the box indicates the median. The lines running vertically from the box (whiskers) extend to the highest and lowest values, excluding outliers, which are denoted by circles. Source habitats: sf, sorghum field; fm, sorghum field margin; rd, roadside; sc, sugarcane field; pk, national park. 
Table 3

Eigenvalues, Component Loadings, and Amount of Total Variance from Principal Component Analysis (PCA)

\begin{tabular}{lrrr}
\hline & PC1 & PC2 & PC3 \\
\hline Eigenvalue & 1.65 & .96 & .88 \\
Component loadings: & & & \\
$\quad$ Plant height & -.42 & .15 & .76 \\
No. internodes & -.53 & -.27 & .24 \\
No. basal tillers & .23 & -.93 & .17 \\
Panicle length & .49 & .22 & .43 \\
Panicle width & .50 & & .39 \\
Proportion of variance & .56 & .19 & .16 \\
Cumulative proportion of variance & .56 & .75 & .91 \\
\hline
\end{tabular}

Note. PCA performed on five quantitative morphological traits as indicated. Only the first three principal components are shown.

can be found intermixed with and adjacent to cultivated types (Tesso et al. 2008; Barnaud et al. 2009; Mutegi et al. 2010).

\section{Variability between Wild Morphotypes: Evidence for Crop-to-Wild Gene Flow?}

Our analysis based on PCA (fig. 4) separated wild sorghum populations in this study into two morphotypes, which unambiguously corresponded to the field assignment of samples to putative hybrid and true wild categories. Similar results were obtained with cluster analysis (fig. 5), with further separation of putative hybrid types according to habitat type: intermediate and sorghum field. Taken together, these results provide a compelling case for crop-to-wild introgression in populations of wild sorghum occurring in crop fields and intermediate habitats. According to the PCA analysis, morphological delineation was highly influenced by four traits of vigor: plant height, number of internodes, panicle length, and panicle width. Members of putative hybrid appeared to be more vigorous than their true wild counterparts, which may reflect hybrid heterosis in populations of the former. Putative hybrid was also characterized by compact to semicompact panicle types, a characteristic that is typical of cultivated sorghum types. The opposite was observed in the true wilds, with members of this group having open and loose panicle types. The separation revealed between populations of putative hybrids found in sorghum fields and those found in intermediate habitats may reflect differences in the magnitude of crop-to-wild gene flow.

The dynamics of gene introgression between cultivated and wild/weedy sorghum can be highly influenced by farmer practices (Barnaud et al. 2009). Farmers in Lambwe Valley, Suba District, belong to the Luo tribe and subtribe, the Abasuba, who practice traditional farming methods. During the crop growth cycle, hand weeding is carried out either once or twice, depending on the size of the field and labor available

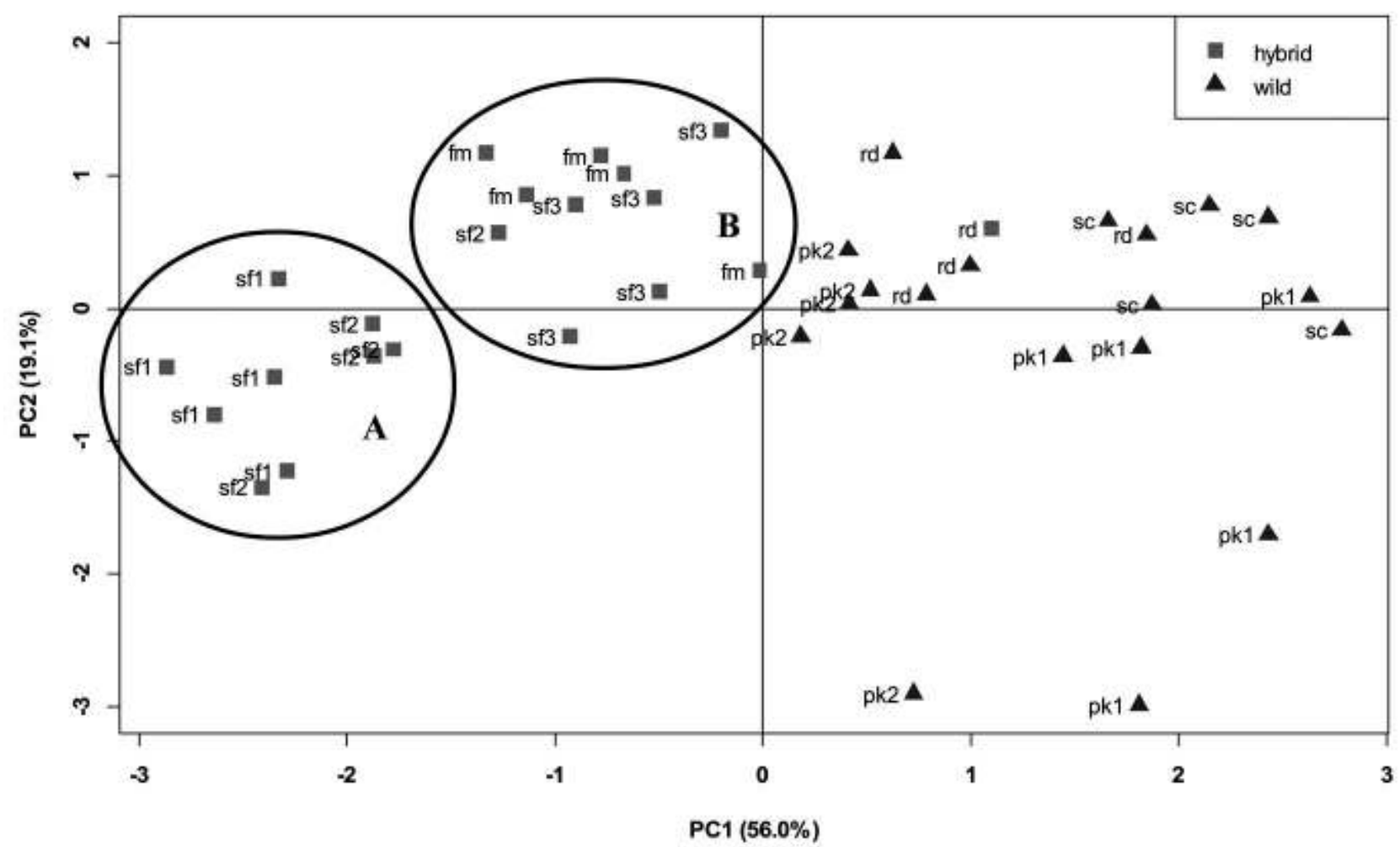

Fig. 4 Biplot of the first two principal components (PC1, PC2) based on five quantitative traits recorded. PC1 and PC2 explain $56.0 \%$ and $19.1 \%$ of the total variability among individuals, respectively. Source habitats: sf, sorghum field; fm, sorghum field margin; rd, roadside; sc, sugarcane field; pk, national park. Separation of putative hybrids into two groups (A and B) is shown. 


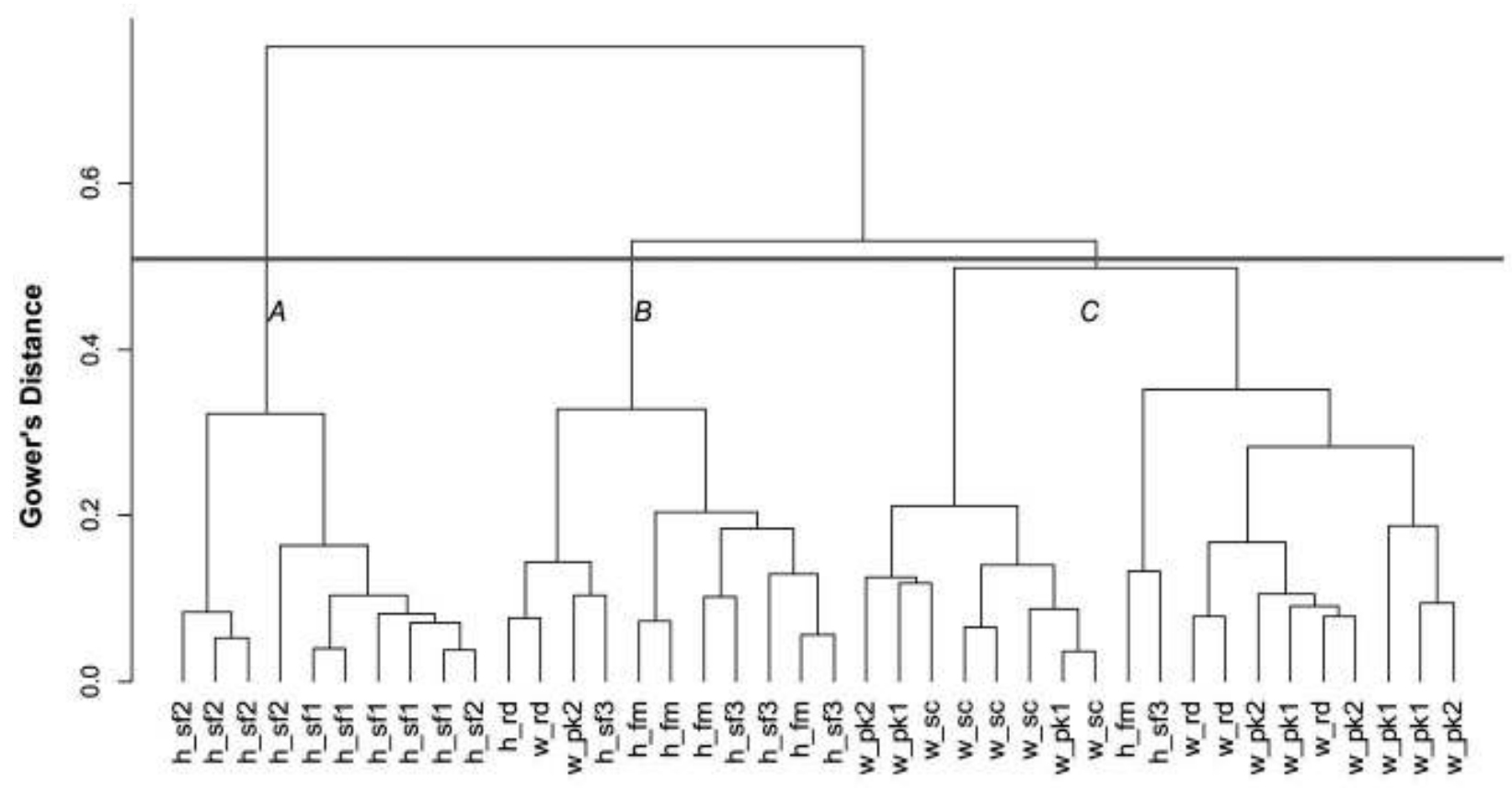

Fig. 5 Dendogram of the hierarchical cluster analysis performed on 40 wild and weedy sorghum and five quantitative traits based on a pairwise Gower's dissimilarity coefficient as labeled by habitat (with A, B, and C representing three main morphological groupings at $\sim 56 \%$ dissimilarity).

per household. In our investigation, we found weedy and cultivated sorghums sympatric with each other, with weedy sorghums either in sorghum fields or by field margins. We also observed that farmers in this ecosystem maintain their own sorghum landraces, originally received from a relative of the same village or from another village, while a few are purchased from the local markets. These different sorghum landraces were often found grown mixed in the same farmer's field. This practice of growing numerous landraces in a single field favors extensive pollen flow (Barnaud et al. 2008). Gene flow plays a role in structuring the genetic variability within and among populations, and its consequences can contribute to the scientific basis for managing agricultural systems, understanding evolutionary processes, and designing in situ conservation measures for genetic resources and using these resources to secure current and future plant breeding programs (Schmidt and Bothma 2006; Barnaud et al. 2007; Mutegi et al. 2010). Although our conclusions are however consistent with previous studies based on morphological data both at the national level (Ejeta and Grenier 2005; Tesso et al. 2008; Mutegi et al. 2010) and at the local or village level (Barnaud et al. 2009), further analysis with molecular markers, using samples of both cultivated and wild sorghum, is necessary to validate this hypothesis on occurrence and magnitude of crop-to-wild gene flow.

\section{Acknowledgments}

The funds from the Biosafety Institute for Genetically Modified Agricultural Products, Iowa State University, for the visiting scientist program enabled J. A. Okeno to participate in this study. Also appreciated is Dr. Kendall Lamkey, Chair of the Department of Agronomy, Iowa State University, for providing an Agronomy Endowment travel grant to J. A. Okeno to make a reconnaissance trip to sorghum fields in Lambwe Valley, Kenya. We are also grateful to Zachary Muthamia for logistical support we obtained from the National Gene Bank of Kenya. We highly acknowledge the entry permit and security accorded us by the Kenya Wildlife Services to enter and collect wild sorghum in Ruma National Park. Last, but not least, we are indebted to Jonathan Hirsi, Charles Ndiege, and Richard Otip for participating in all sample collection trips.

\section{Literature Cited}

Aldrich PR, J Doebley 1992 Restriction fragment variation in the nuclear and chloroplast genomes of cultivated and wild Sorghum bicolor. Theor Appl Genet 85:293-302.

Aldrich PR, J Doebley, KF Schertz, A Stec 1992 Patterns of allozyme variation in cultivated and wild Sorghum bicolor. Theor Appl Genet 85:451-460.

Arriola PE, N Ellstrand 1997 Fitness of interspecific hybrids in the genus Sorghum: persistence of crop genes in the wild populations. Ecol Appl 7:512-518.

Barnaud A, M Deu, E Garine, J Chantereau, J Bolteu, EO Koida, D McKey, HI Joly 2009 A weed-crop complex in sorghum: the dynamics of genetic diversity in a traditional farming system. Am J Bot 96:1869-1879.

Barnaud A, M Deu, E Garine, D McKey, HI Joly 2007 Local 
genetic diversity of sorghum in a village in northern Cameroon: structure and dynamics of landraces. Theor Appl Genet 114: 237-248.

Barnaud A, G Triguersos, D McKey, HI Joly 2008 High outcrossing rates in fields with mixed sorghum landraces: how are landraces maintained? Heredity 101:445-452.

Barro-Kondombo C, F Sagnard, J Chantereau, M Deu, K vom Brocke, P Durand, E Gozè, JD Zongo 2010 Genetic structure among sorghum landraces as revealed by morphological variation and microsatellite markers in three agroclimatic regions of Burkina Faso. Theor Appl Genet 120:1511-1523.

Casa AM, SE Mitchell, MT Hamblin, H Sun, JE Bowers, AH Paterson, CF Aquadro, S Kresovich 2005 Diversity and selection in sorghum: simultaneous analyses using simple sequence repeats. Theor Appl Genet 111:23-30.

de Vries J, G Toenniessen 2001 Securing the harvest: biotechnology, breeding and seed systems for African crops. CABI, Wallingford.

de Wet JMJ, JR Harlan, EG Price 1970 Origin of variability in the spontanea complex of sorghum bicolor. Am J Bot 57:704-707.

de Wet JMJ, JP Huckabay 1967 Origin of Sorghum bicolor. II. Distribution and domestication. Evolution 21:787-802.

Djè Y, M Heuertz, M Ater, C Lefèbvre, X Vekemans 2000 Assessment of genetic diversity within and among germplasm accession in cultivated sorghum using microsatellite markers. Theor Appl Genet 100:918-925.

Doggett H 1988 Sorghum. 2nd ed. Wiley, New York.

Doggett H, BN Majisu 1968 Disruptive selection in crop development. Heredity 23:1-26.

Doggett H, KE Prasada Rao 1995 Sorghum. Pages 173-180 in J Smartt, NW Simmonds, eds. Evolution of crop plants. 2nd ed. Longman, Harlow.

Duncan RR, PJ Bramel-Cox, FR Miller 1991 Contributions of introduced sorghum germplasm to hybrid development in the USA. Pages 69-101 in HL Shands, LE Wiesner, eds. Use of plant introductions in cultivar development. Crop Sci Soc Am Spec Publ 17, Madison.

Ejeta G, C Grenier 2005 Sorghum and its weedy hybrids. Pages 123135 in J Gressel, ed. Crop ferality and volunteerism. CRC, Boca Raton, FL.

Ellstrand NC, HC Prentice, JF Hancock 1999 Gene flow and introgression from domesticated plants into their wild relatives. Annu Rev Ecol Syst 30:539-556.

Gower JC 1971 A general coefficient of similarity and some of its properties. Biometrics 27:623-637.

Harlan JR, JMJ de Wet 1972 A simplified classification of cultivated sorghum. Crop Sci 12:172-176.

Kamala V, HC Sharma, D Manohar Rao, KS Varaprasad, PJ Bramel 2009 Wild relatives of sorghum as sources of resistance to sorghum shoot fly, Atherigona soccata. Plant Breed 128:137-142.

Kamala V, SD Singh, PJ Bramel, DM Rao 2002 Sources of resistance to downy mildew in wild and weedy sorghums. Crop Sci 42:1357-1360.

Kaufman L, PJ Rousseeuw 1990 Finding groups in data: an introduction to cluster analysis. Wiley, New York.

Legendre P, L Legendre 1998 Numerical ecology. 2nd ed. Elsevier, Amsterdam.

Mann JA, CT Kimber, FR Miller 1983 The origin and early cultivation of sorghums in Africa. Bulletin 1454. Texas A \& M University, College Station.

Maxted N, SP Kell, A Toledo, ME Dulloo, V Heywood, T Hodgkin, D Hunter, L Guarino, A Jarvis, BV Ford-Lloyd 2010 A global approach to crop wild relative conservation: securing the gene pool for food and agriculture. Kew Bull 65:561-576.

Morrell PL, TD Williams-Coplin, AL Lattu, JE Bowers, JM Chandler, AH Paterson 2005 Crop-to-weed introgression has impacted allelic composition of Johnsongrass populations with and without recent exposure to cultivated sorghum. Mol Ecol 14:2143-2154.

Mutegi E, F Sagnard, M Muraya, B Kanyenji, B Rono, C Mwongera, C Marangu, et al 2010 Ecogeographical distribution of wild, weedy and cultivated Sorghum bicolor in Kenya: implications for conservation and crop-to-wild gene flow. Genet Resour Crop Evol 57:243-253.

Mutegi E, F Sagnard, K Semagn, M Deu, M Muraya, B Kanyenji, S de Villiers, D Kiambi, L Herselman, M Labuschagne 2011 Genetic structure and relationships within and between cultivated and wild sorghum (Sorghum bicolor (L.) Moench) in Kenya as revealed by microsatellite markers. Theor Appl Genet 122:989-1004.

Paterson AH, KF Schertz, YR Lin, SC Liu, YL Chang 1995 The weediness of wild plants: molecular analysis of genes influencing dispersal and persistence of Johnsongrass, Sorghum halepense (L.) Pers. Proc Natl Acad Sci USA 92:6127-6131.

R Development Core Team 2008 R: a language and environment for statistical computing. R Foundation for Statistical Computing, Vienna. http://www.R-project.org.

Reed JD, BA Ramundo, LF Claflin, MR Tuinstra 2002 Analysis of resistance to ergot in sorghum and potential alternate hosts. Crop Sci 42:1135-1138.

Schmidt M, G Bothma 2006 Risk assessment for transgenic sorghum in Africa crop-to-crop gene flow in Sorghum bicolor (L.) Moench. Crop Sci 46:790-798.

Sharma HC, BA Franzmann 2001 Host plant preference and oviposition responses of the sorghum midge, Stenodiplosis sorghicola (Coquillett) (Dipt., Cecidomyiidae) towards wild relatives of Sorghum. J Appl Entomol 125:109-114.

Tanksley SD, SR McCouch 1997 Seed banks and molecular maps: unlocking genetic potential from the wild. Science 277:1063-1066.

Tesso T, I Kapran, C Grenier, A Snow, P Sweeney, J Pedersen, D Marx, G Bothma, G Ejeta 2008 The potential for crop-to-wild gene flow in sorghum in Ethiopia and Niger: a geographic survey. Crop Sci 48: 1425-1431. 